\title{
Calorie 4 Degrees Celsius
}

National Cancer Institute

\section{Source}

National Cancer Institute. Calorie 4 Degrees Celsius. NCI Thesaurus. Code C68847.

A non-SI unit of energy defined as the amount of heat required to raise the temperature of one gram of pure water by one degree (from 3.5 to $4.5 \mathrm{C}$ or from 276.65 to $277.65 \mathrm{~K}$ ) under standard conditions with the specific heat of the water at 4 degrees Celsius and the constant pressure of $101.325 \mathrm{kPa}$ or one atm being defined as unity. A value of the calorie at 4 degrees Celsius is defined as $4.2045 \mathrm{~J}$. According to the current national standard in the United States (IEEE/AST M SI 10T M 2002. American National Standard for Use of the International System of Units (SI): The Modern Metric System, New York: IEEE, 2002) the calorie in any form is not to be used. Joules should be used instead. 